\title{
Capparis macrantha sp. nov. (Capparaceae, Brassicales), a new shrub species from a deciduous forest of the Nam Kading National Protected Area (central Lao PDR)
}

\author{
Keooudone SOUVANNAKHOUMMANE ${ }^{1}$, Silvio FICI ${ }^{2, *}$, Soulivanh LANORSAVANH ${ }^{3}$, \\ Jeong Ho PARK ${ }^{4}$, Ho Sang KANG ${ }^{5} \&$ Chaloun BOUNITHIPHONH ${ }^{6}$ \\ ${ }^{1}$ The Agro-Biodiversity Initiative, National Agriculture and Forest Research Institute, \\ Vientiane, Lao PDR. \\ ${ }^{2}$ Department of Agricultural, Food and Forest Sciences, University of Palermo, Palermo, Italy. \\ ${ }^{3}$ Biology Department, Faculty of Natural Science, National University of Laos, Vientiane, Lao PDR. \\ 4,5 International Environmental Cooperation Center, National Instrumentation Center
} for Environmental Management, Seoul National University, Seoul, 08826, Republic of Korea. ${ }^{6}$ Forest Ecology and Environmental Research Unit, National Agriculture and Forest Research Institute, Vientiane, Lao PDR.

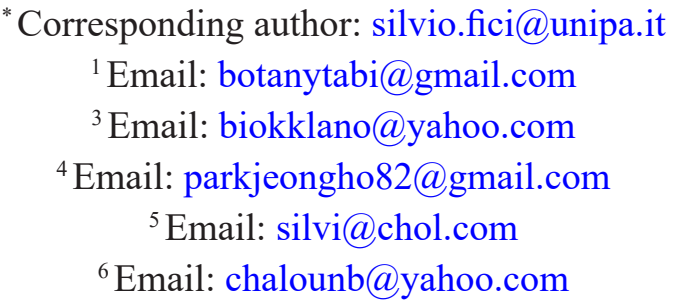

\begin{abstract}
Capparis macrantha Souvannakhoummane, Fici \& Lanorsavanh sp. nov., a new shrub species characterized by erect or ascending habit, stipular thorns, large lanceolate-elliptic leaves and large flowers in supra-axillary rows, is described and illustrated from the deciduous forest in Nam Kading National Protected Area (central Lao PDR). The new species belongs to Capparis sect. Monostichocalyx Radlk. and is morphologically similar to C. radula Gagnep., a shrub widespread in the Indochinese area, differing in the shorter, straight stipular thorns, larger leaves, larger sepals and petals, higher number of stamens with longer filaments and longer gynophore and ovary. Its affinities with related taxa are discussed and a key is provided for the species of Capparis L. known from Lao PDR. The conservation status of the new species is provisionally assessed as Vulnerable (VU D1).
\end{abstract}

Keywords. Bolikhamxai Province, Capparaceae, Capparis sect. Monostichocalyx, diversity, ecology.

Souvannakhoummane K., Fici S., Lanorsavanh S., Park J.H., Kang H.S. \& Bounithiphonh C. 2020. Capparis macrantha sp. nov. (Capparaceae, Brassicales), a new shrub species from a deciduous forest of the Nam Kading National Protected Area (central Lao PDR). European Journal of Taxonomy 656: 1-12. https://doi.org/10.5852/ejt.2020.656 


\section{Introduction}

The flowering plant genus Capparis L. (Capparaceae Juss., Brassicales Bromhead) includes about 140 species (POWO 2019) of shrubs, small trees and climbers widespread in the tropical and subtropical areas of the Old World, with outliers in central Asia and the Mediterranean Region, and occurring from sea level up to ca $3600 \mathrm{~m}$ a.s.l. over a wide range of habitats, e.g., bushlands, savannahs, dry evergreen, deciduous or rain forests, rocky habitats, coastal vegetations, forest margins, etc. The Indochinese Peninsula is a major centre of speciation of Capparis, but its taxonomic treatment is still critical in Lao PDR where a discordant number of species has been recorded by different authors (Gagnepain 1908; Jacobs 1965; Newman et al. 2007; Inthakoun \& Delang 2008; Lee 2016). Field and herbarium research carried out in the last years in this country have provided new data on the variation and distribution of various poorly known taxa (Fici 2016) and led to the description of three new species from the Hin Nam No and Hin Boun National Protected Areas in central Lao PDR (Fici et al. 2018, 2020; Souvannakhoummane et al. 2018). Furthermore a number of new species of Capparis were recently described from neighbouring countries, i.e., Vietnam (Thuong et al. 2013, 2015), Thailand (Srisanga \& Chayamarit 2004) and China (Zhang \& Tucker 2008).

Nam Kading, located in the Bolikhamxai Province, is a poorly explored national protected area of central Lao PDR showing a highly diverse vascular flora. Floristic surveys carried out in this area during the last few years provided documentation of several taxa new for the flora of Lao PDR and led to the description of various new species (Souladeth et al. 2017, 2019; Tagane et al. 2017, 2018; Yang et al. 2018; Souvannakhoummane et al. 2019). During recent field work in the deciduous forest of Nam Kading NPA, a population of Capparis characterized by large, serial flowers, a high number of stamens and a large ovary was observed. Based on herbarium investigations, material collected from this population turned out to belong to a new species of sect. Monostichocalyx Radlk. The new species is here described and illustrated, and data on its distribution, ecology, conservation status and affinities are furnished.

\section{Material and methods}

Field investigations were carried out in the Nam Kading National Protected Area from 2017 to 2019. The new species was first observed and collected by one of us (S.L.) in May 2019 in the deciduous forest of this area and the specimens are kept at the National University of Laos (FOF) and Herbier National du Laos (HNL).

The description and illustration are based on herbarium material. The species concept adopted follows the one proposed by Jacobs (1965) in his revision of the genus Capparis from the Indus to the Pacific. The terminology of vegetative and reproductive structures, as well as the main diagnostic characters within the genus, are based on the same treatment (Jacobs 1965). The herbarium acronyms follow Thiers (2017), while authors and names of plants are based on the IPNI (2018). The conservation status was provisionally assessed according to IUCN Red List Categories and Criteria (IUCN 2012). 


\title{
Results
}

\author{
Class Magnoliopsida Brongn. \\ Order Brassicales Bromhead \\ Family Capparaceae Juss. \\ Genus Capparis L. \\ Section Monostichocalyx Radlk.
}

Capparis macrantha Souvannakhoummane, Fici \& Lanorsavanh sp. nov. urn:lsid:ipni.org:names:77209673-1

Figs 1-2

\section{Type material}

LAO PDR - Bolikhamxai Province, Pakkading district, Nam Kading National Protected Area; $221 \mathrm{~m}$ a.s.1.; 16 May 2019; Lanorsavanh et al. SL1641; holotype: HNL, isotype: FOF.

\section{Diagnosis}

A C. radula Gagnep. stipulis rectis brevioribus, foliis majoribus, sepalis petalisque majoribus, staminum numero superiore, filamentis longioribus, gynophoro atque ovario longioribus praecipue differt.

\section{Etymology}

The specific epithet is composed of the Greek words 'makrós', meaning 'large', and 'ánthos', 'flower'.

\section{Description}

Erect or ascending shrub 1-3 m tall. Branches greyish, bearing small knobs surmounted by a thorn; twigs when young pubescent with simple hairs, later glabrous, at the base usually surrounded by cataphylls. Stipular thorns straight, directed upwards or slightly recurved, ca $2 \mathrm{~mm}$ long. Petioles 10-24 mm long, glabrous. Leaf blades coriaceous, lanceolate-elliptic, ca 3.7-4.1 times as long as wide, 30-36×7.5$10.5 \mathrm{~cm}$; base obtuse or rounded; apex acute or acuminate, with tip $0.8-1.4 \mathrm{~cm}$ long; upper surface dark green, lower surface light green, both ones glabrous; veins ca 8-12 on each side of the midrib, decurrent along the margin; young leaves pubescent, silver to pale green with purple patch near apex. Flowers white, fragrant, serial, 2-4 in supra-axillary rows; pedicels $3.5-4.2 \mathrm{~cm}$ long, glabrous, surrounded at base by conferted bracts; bracts triangular, ca $1.8 \mathrm{~mm}$ long. Sepals $2-2.5 \times 0.7-1 \mathrm{~cm}$, greenish, acute at apex, glabrous on both sides, outer pair boat-shaped, inner pair thinner. Petals oblong to obovate, $3.5-$ $4.5 \times 1.2-2.6 \mathrm{~cm}$, puberulous outside, white with yellow or purple honey-guide. Stamens ca 100-135; filaments ca 3.5-4.5 cm long; anthers 1.8-2 mm long. Gynophore 3.8-4.2 cm long, glabrous; ovary ellipsoid or oblong, 5-6×1.7-2 mm, glabrous, shortly beaked with small knob-shaped stigma. Fruit unknown.

\section{Distribution, habitat and phenology}

The new species is so far known from a single location in the Nam Kading National Protected Area in Bolikhamxai Province, at $18^{\circ} 11^{\prime} 44.9^{\prime \prime} \mathrm{N}, 104^{\circ} 26^{\prime} 25.1^{\prime \prime}$ E (Fig. 3). Capparis macrantha sp. nov. has been observed in mixed deciduous forest on limestone, at ca 200-230 m elevation, with Amorphophallus laoticus Hett., Arisaema Mart. sp., Wurfbainia glabrifolia (Lamxay \& M.F.Newman) Škorničk. \& A.D.Poulsen. The flowering occurs from May to June.

\section{Taxonomic remarks}

Capparis macrantha sp. nov. is mainly distinguished from other species of sect. Monostichocalyx by its large flowers in supra-axillary rows, as well as by its large leaves, high number of stamens and elongate 


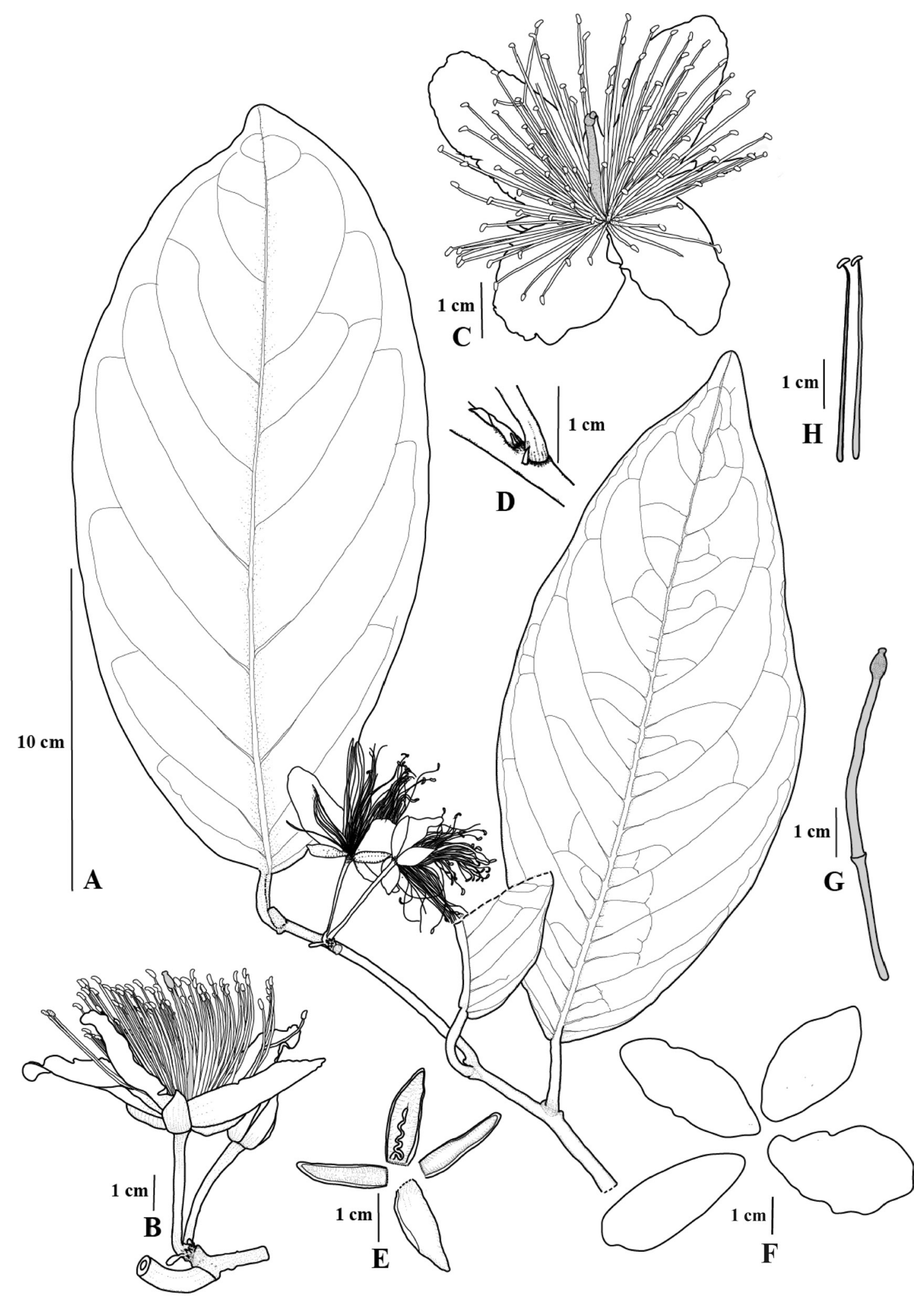

Fig. 1. Capparis macrantha Souvannakhoummane, Fici \& Lanorsavanh sp. nov. A. Flowering branch. B. Flower (lateral view). C. Flower (front view). D. Stipular thorn and petiole. E. Sepals. F. Petals. G. Gynophore and ovary. H. Stamens. Drawn from holotype (Lanorsavanh et al. SL1641) by K. Souvannakhoummane. 

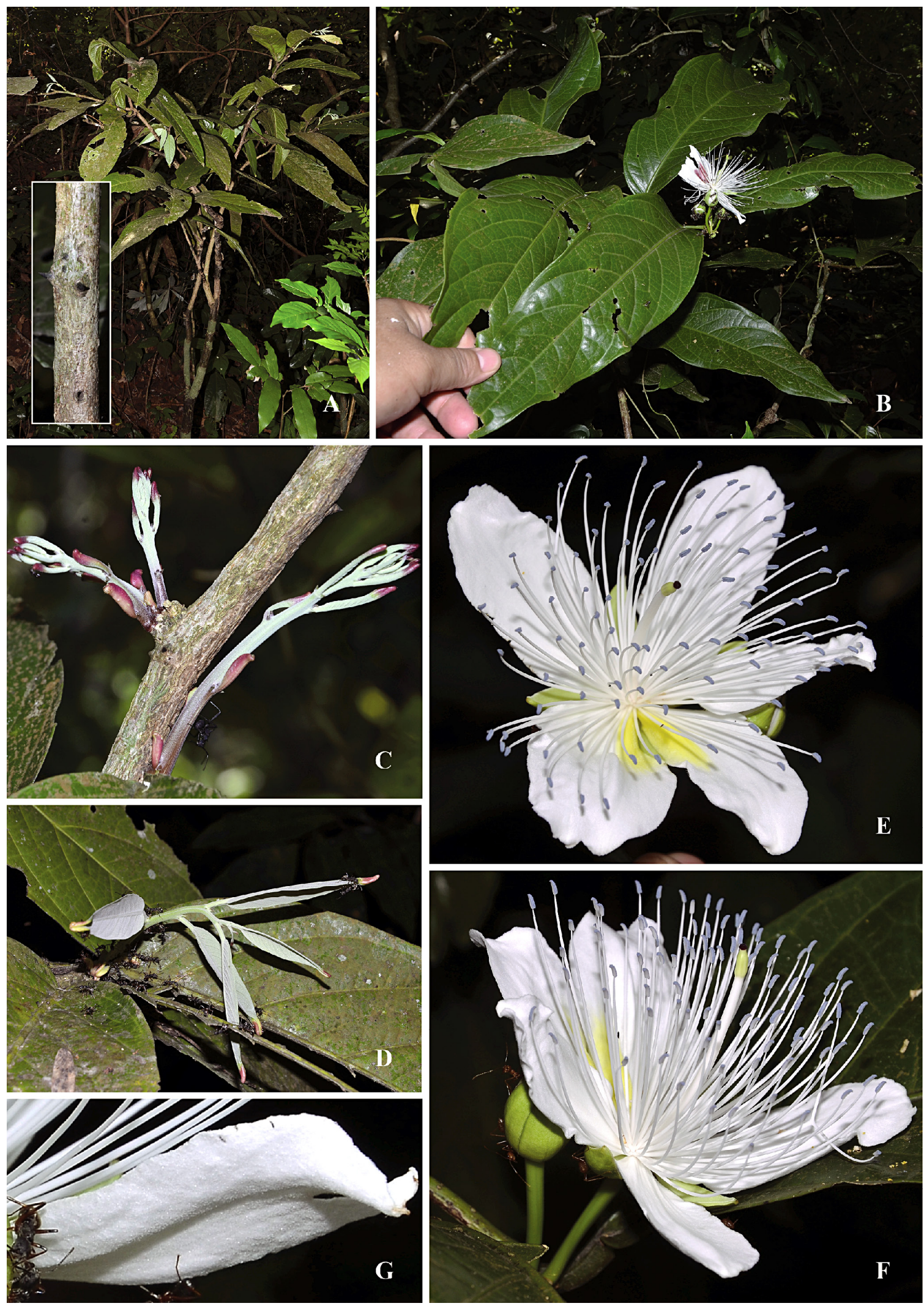

Fig. 2. Capparis macrantha Souvannakhoummane, Fici \& Lanorsavanh sp. nov. A. Habit and detail of a branch bearing thorns. B. Flowering branch. C. Young twigs. D. Young leaves. E. Flower (top view). F. Flower (lateral view). G. Petal (outside view). Photos by S. Lanorsavanh. 


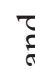

产

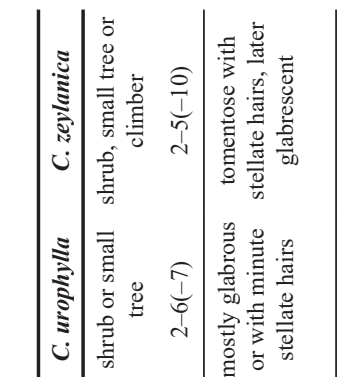

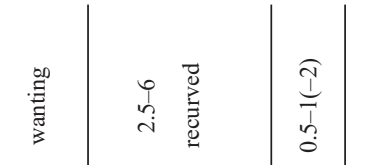

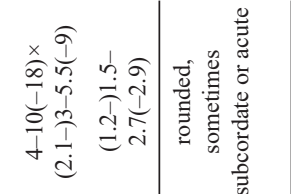

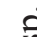

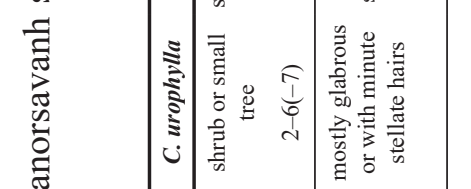

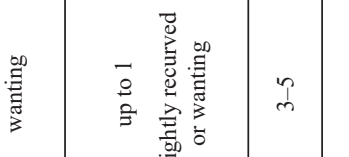

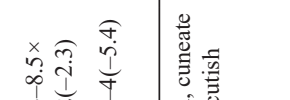

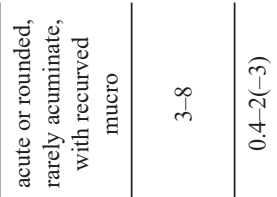

$\infty$

$\sqrt{1}$

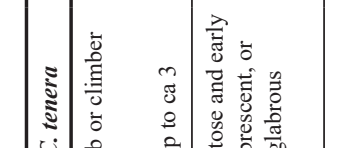

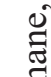

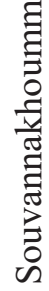

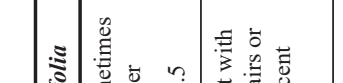

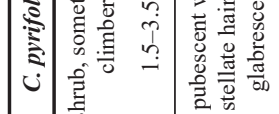

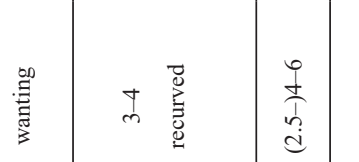

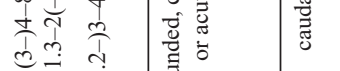

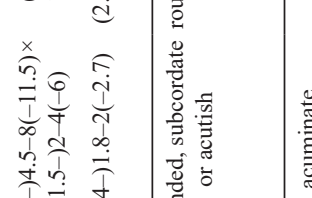

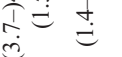

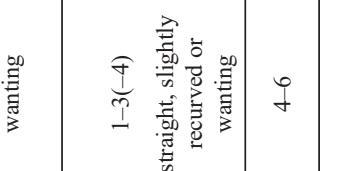

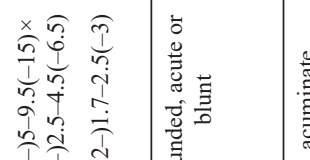

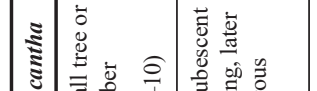

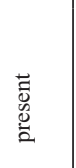

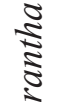

छ)

竎

乡

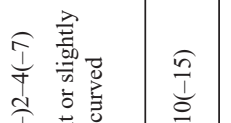

एव

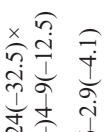

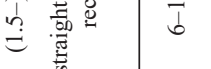

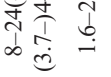

量

章

$\widehat{\bar{t}}$

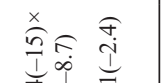

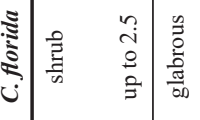

छ

๕ี

के

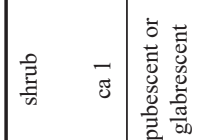

引

量

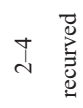

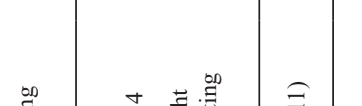

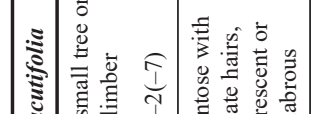

.0.0

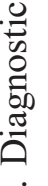

(ิ)

范

$\nsubseteq$

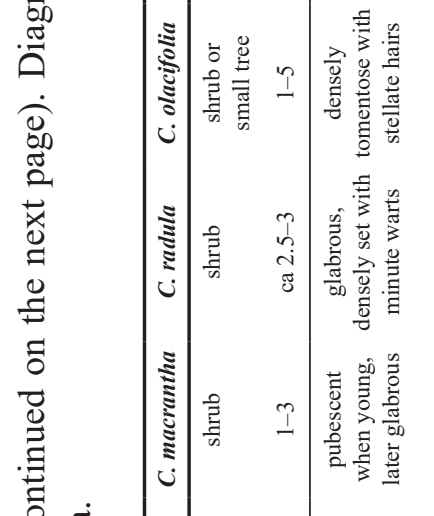

量

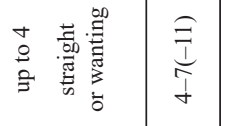

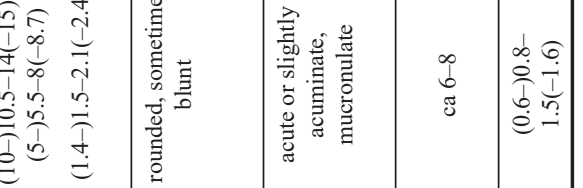

ن 解

:

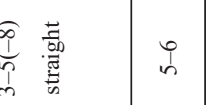

ำ

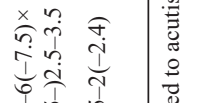

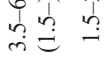

离的

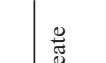

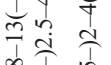

री

过

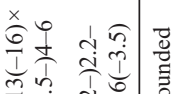

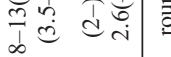

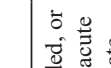

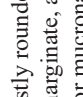

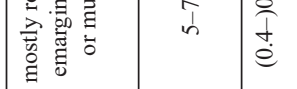

2.

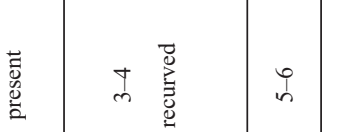

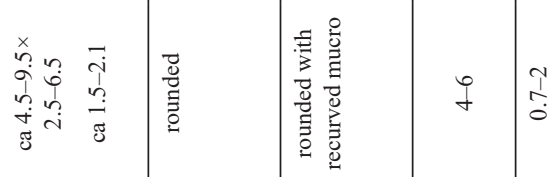

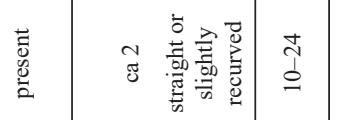

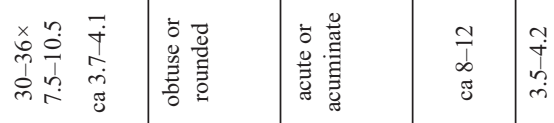

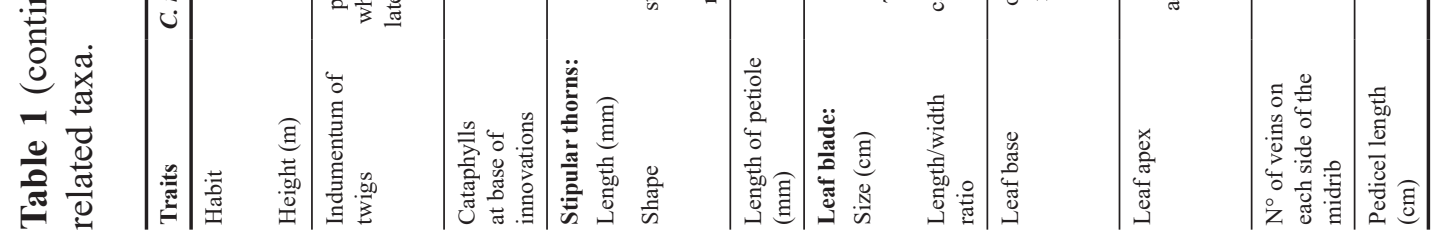




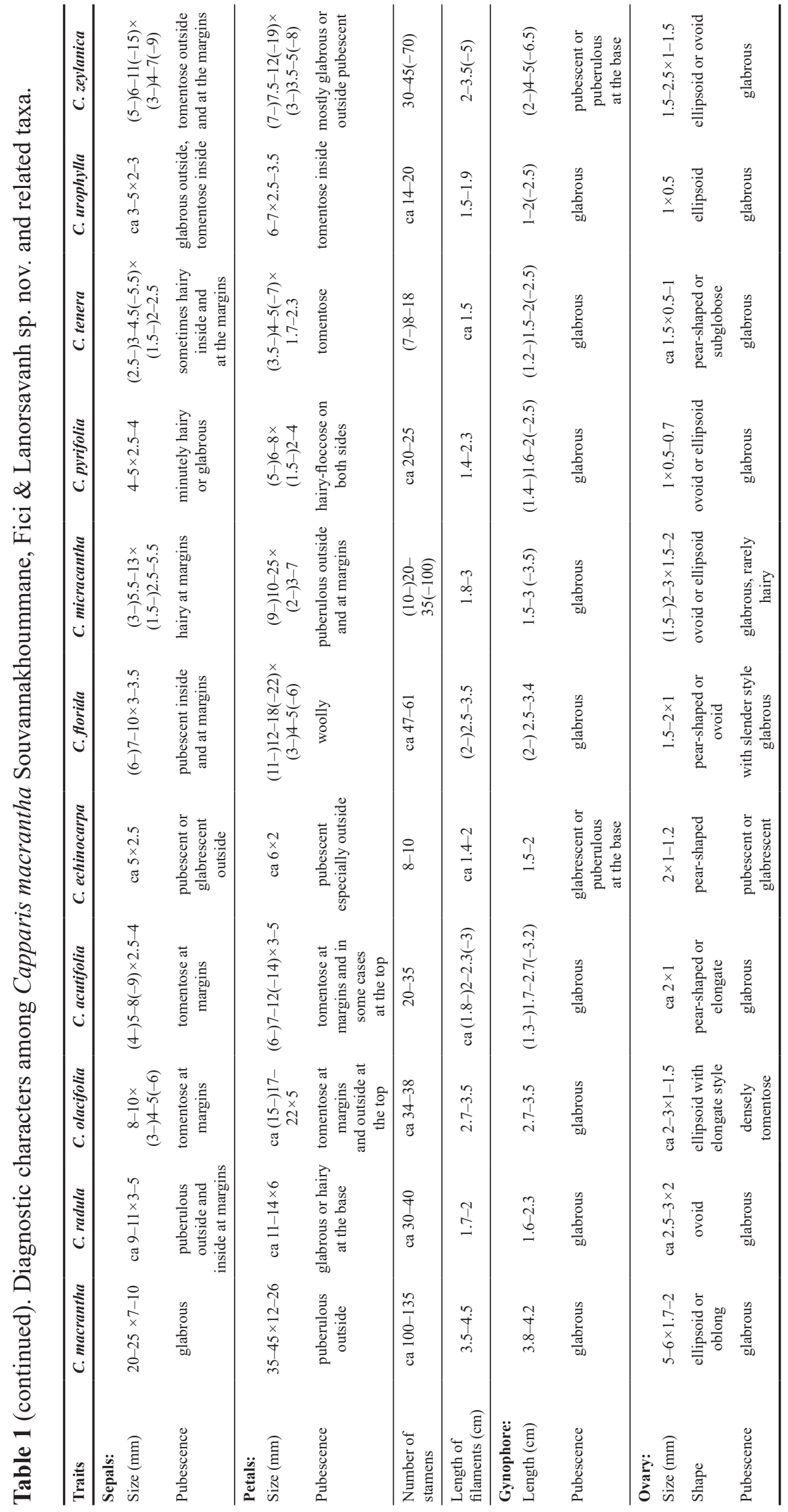


ovary. Among the species of the genus with serial flowers, C. macrantha sp. nov. shows some affinities with C. radula, recorded in Thailand, Lao PDR, Cambodia and Vietnam, which however differs in the longer, recurved stipular thorns 3-4 mm long, smaller leaves ca $4.5-9.5 \times 2.5-6.5 \mathrm{~cm}$, smaller flowers with sepals ca $9-11 \times 3-5 \mathrm{~mm}$ and petals ca $11-14 \times 6 \mathrm{~mm}$, lower number of stamens (ca 30-40) with filaments $1.75-2 \mathrm{~cm}$ long, shorter gynophore $1.6-2.3 \mathrm{~cm}$ long and shorter, ovoid ovary ca $2.5-3 \mathrm{~mm}$ long (Jacobs 1965) (Table 1). The new species is also related to C. olacifolia Hook.f. \& Thomson, widespread from India and Nepal eastwards to Myanmar, which is distinguished by the smaller leaves 8-13(-16) $\times(3.5-) 4-6 \mathrm{~cm}$, smaller flowers with sepals $8-10 \times(3-) 4-5(-6) \mathrm{mm}$ and petals $(15-) 17-$ $22 \times$ ca $5 \mathrm{~mm}$, lower number of stamens (34-38) and densely tomentose ovary 1-1.5 mm wide (Table 1 ). Various other species recorded from Lao PDR and included by Jacobs (1965) in the Seriales-Group, as C. acutifolia Sweet, C. echinocarpa Pierre ex Gagnep., C. micracantha DC., C. pyrifolia Lam., C. tenera Dalzell, C. urophylla F.Chun and C. zeylanica L., are readily distinguished by their small to medium sized flowers, with sepals $3-15 \mathrm{~mm}$ long, and by the ovary up to ca $3 \mathrm{~mm}$ long (Table 1 ).

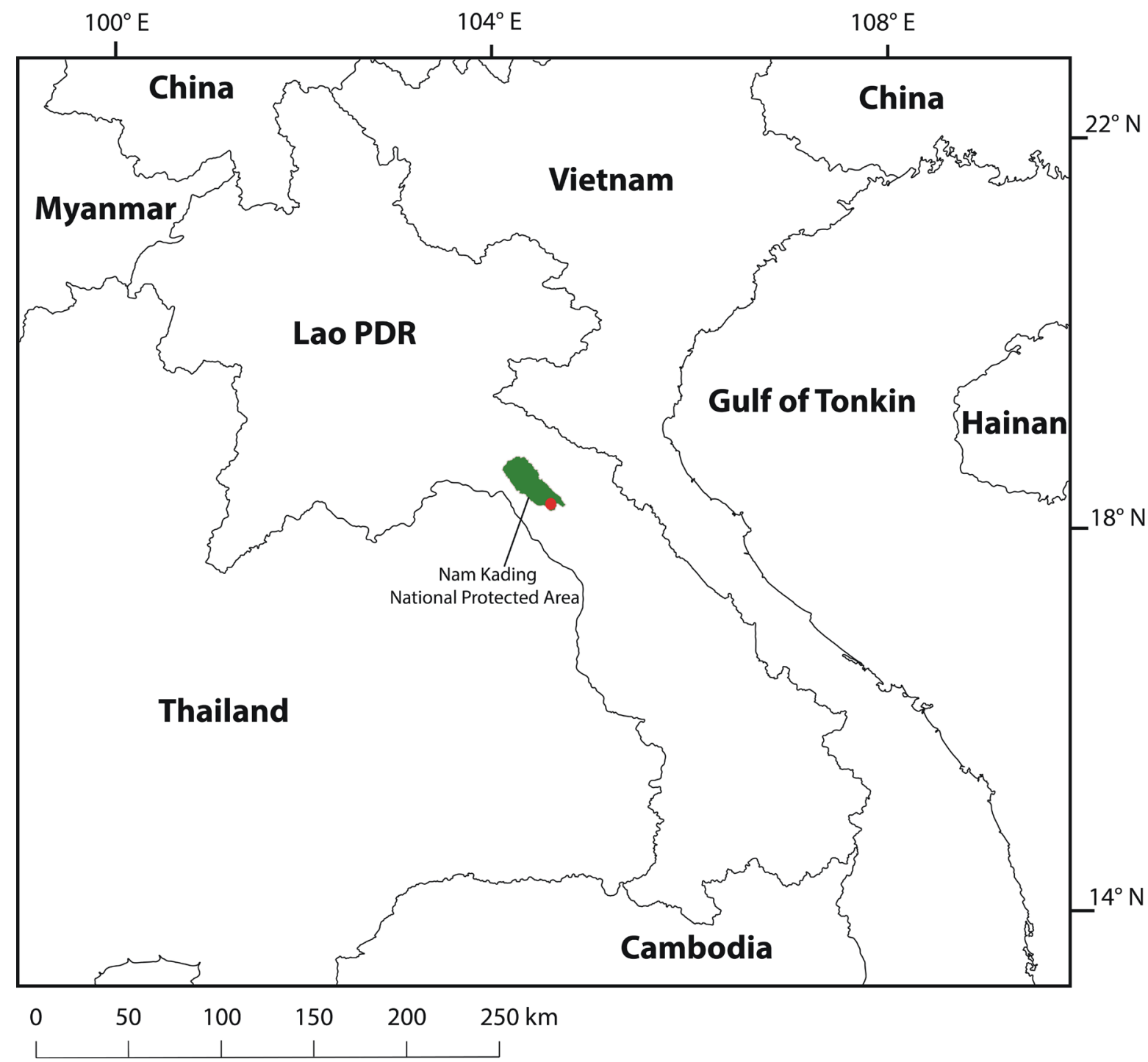

Fig. 3. Known distribution of Capparis macrantha Souvannakhoummane, Fici \& Lanorsavanh sp. nov. (red circle). 


\section{Conservation status}

Capparis macrantha sp. nov. is known from the type locality only, occurring in a National Protected Area, where about 10 individuals were observed. Based on our observations, the population is not under immediate threat; however, given the very small area of occupancy known, the new species is assessed here as Vulnerable (VU D1) according to IUCN Red List Categories and Criteria (IUCN 2012).

\section{Discussion}

The genus Capparis is represented in Lao PDR by about twenty species (Jacobs 1965; Newman et al. 2007; Fici et al. 2018, 2020; Souvannakhoummane et al. 2018), all belonging to sect. Monostichocalyx, characterized by leaves well developed and persistent, and sepals all free in bud, with both sepals of a pair equal (Jacobs 1965) (for a key to the species of Capparis L. in Lao PDR see Supplementary file 1). Other sections of the genus recorded in southern Asia and the Pacific, i.e., sect. Capparis L., sect. Sodada (Forssk.) Endl. and sect. Busbeckea (Endl.) Benth. \& Hook.f. (Jacobs 1965; Fici 2017), are not represented in the Indochinese area. Jacobs (1965) recognized within sect. Monostichocalyx some tentative morphological groups, among which the Seriales-Group includes several species with small to medium-sized flowers arranged in supra-axillary rows. However, the same author underlined that, within the whole genus, the species with serial flowers "are the most difficult to interpret. Most of them have advanced characters, some are taxonomically isolated"; based on his statement that "a serial arrangement of flowers does not imply a common origin", Jacobs (1965) treated a few species showing this reproductive feature in other groups, i.e., C. multiflora Hook.f. \& Thomson in the CataphyllosaGroup (including species with flowers small to large, usually arranged on a bracteate, leafless axis or subumbellate, rarely serial), and C. olacifolia and C. radula in the Brevispina-Group (including species with flowers mostly large and solitary, rarely serial, with elongate ovary). Due to its flower characters, C. macrantha sp. nov. could be better placed in the latter group than in the Seriales one; it is to be underlined that the large size of the flowers and the high number of stamens found in the new species are unusual for sect. Monostichocalyx. With regard to southern Asia, flowers of similar size are recorded in a few species, i.e., C. baducca L. from southern India, differing in the smaller leaves, (7-)9-14×(3.5-)4$5.5(-6.5) \mathrm{cm}$, and in the solitary, axillary flowers, and C. trisonthiae Srisanga \& Chayam., a species described from Doi Phu Kha National Park in northern Thailand (Srisanga \& Chayamarit 2004), which differs in the lianous habit and flowers arranged in terminal leafy panicles.

The discovery of this new species confirms the role of the limestone habitats of Lao PDR in the differentiation in south-eastern Asia of the genus Capparis, which includes several taxa endemic to this country, among which are C. lanceolatifolia Fici, Bouaman. \& Souvann., C. hinnamnoensis Souvann. \& Fici and C. florida Fici \& Souvann., three species recently described from the Khammouan Karst. With regard to the floristic relevance of Nam Kading NPA, during the last years various new species were described from this area, e.g., Strobilanthes namkadingensis Soulad. \& Tagane (Acanthaceae Juss.), Begonia namkadingensis C.J.Yang, Soulad. \& Tagane (Begoniaceae C.Agardh), Monoon namkadingense Soulad. \& Tagane and Neo-uvaria laosensis Tagane \& Soulad. (Annonaceae Juss.), Didymocarpus middletonii Souvann., Soulad. \& Tagane (Gesneriaceae Dumort.), Camellia namkadingensis Soulad. \& Tagane and C. rosacea Tagane, Soulad. \& Yahara (Theaceae Mirb. ex Ker Gawl.) (Souladeth et al. 2017, 20199; Tagane et al. 2018; Yang et al. 2018; Souvannakhoummane et al. 201). Further floristic research in this less investigated area most likely will add new data to the vascular flora of central Lao PDR.

\section{Acknowledgements}

We are grateful to the staff of the herbaria HNL and FOF for their collaboration. The field survey was supported by the Project No. KNA 1-2-23, 15-4 provided by the Korea Forest Service (Korea 
National Arboretum). The Fondation Franklinia and Muséum National d'histoire Naturelle (Paris) are acknowledged for supporting taxonomic research in south-eastern Asia.

\section{References}

Fici S. 2016. Studies on the genus Capparis L. (Capparaceae) in Lao PDR. Webbia 71: 169-175. http://doi.org/10.1080/00837792.2016.1232928

Fici S. 2017. A taxonomic revision of the genus Capparis (Capparaceae) in New Caledonia. New Zealand Journal of Botany 55: 407-423. https://doi.org/10.1080/0028825X.2017.1361454

Fici S., Bouamanivong S. \& Souvannakhoummane K. 2018. Studies on the genus Capparis L. (Capparaceae) in Lao PDR. II: A new species from the Khammouan karst. Webbia 73: 5-7. http://doi.org/10.1080/00837792.2017.1402476

Fici S., Souvannakhoummane K., Lanorsavanh S. \& Lamxay V. 2020. Studies on the genus Capparis L. (Capparaceae) in Lao PDR. IV: A new species from the Khammouan Province. Phytotaxa 429: 73-79. https://doi.org/10.11646/phytotaxa.429.1.6

Gagnepain F. 1908. Capparidacées. In: Lecomte M.H. (ed.) Flore générale de l'Indo-Chine. Vol 1: 171-206. Masson et C $\mathrm{C}^{\mathrm{ie}}$, Paris. https://doi.org/10.5962/bhl.title.59355

Inthakoun L. \& Delang C.O. 2008. Lao Flora. A Checklist of Plants Found in Lao PDR with Scientific and Vernacular Names. Lulu Press, Morrisville.

IPNI 2018. International Plant Names Index. Available from http://www.ipni.org [accessed 11 Nov. 2019].

IUCN 2012. IUCN Red List Categories and Criteria: Version 3.1. $2^{\text {nd }} \mathrm{ed}$. IUCN, Gland and Cambridge. Jacobs M. 1965. The genus Capparis (Capparaceae) from the Indus to the Pacific. Blumea 12: 385-541. Lee Y.M. 2016. A Checklist of Plants in Lao PDR. Korea National Arboretum, Seoul.

Newman M., Ketphanh S., Svengsuksa B., Thomas P., Sengdala K., Lamxay V. \& Armstrong K. 2007. A Checklist of the Vascular Plants of Lao PDR. Royal Botanic Garden Edinburgh, Edinburgh.

POWO 2019. Plants of the World Online. Facilitated by the Royal Botanic Gardens, Kew. Available from http://www.plantsoftheworldonline.org/ [accessed 17 Mar. 2020].

Souladeth P., Tagane S., Zhang M., Okabe N. \& Yahara T. 2017. Flora of Nam Kading National Protected Area I: a new species of yellow-flowered Strobilanthes (Acanthaceae), S. namkadingensis. PhytoKeys 81: 11-17. https://doi.org/10.3897/phytokeys.81.13203

Souladeth P., Tagane S. \& Yahara T. 2019. Flora of Nam Kading National Protected Area V: two new species of Camellia (Theaceae), C. namkadingensis and C. rosacea. Thai Forest Bulletin Botany 47: 82-90. https://doi.org/10.20531/tfb.2019.47.1.12

Souvannakhoummane K., Fici S., Lanorsavanh S. \& Lamxay V. 2018. Studies on the genus Capparis L. (Capparaceae) in Lao PDR. III: A new species from the deciduous forest of the Hin Nam No National Protected Area. Webbia 73: 175-177. http://doi.org/10.1080/00837792.2018.1470708

Souvannakhoummane K., Souladeth P., Tagane S., Yang C.-J. \& Yahara T. 2019. Flora of Nam Kading National Protected Area VI: Didymocarpus middletonii (Gesneriaceae), A new species from Limestone. Edinburgh Journal of Botany 76: 45-54. https://doi.org/10.1017/S0960428618000264

Srisanga P. \& Chayamarit K. 2004. Capparis trisonthiae (Capparaceae), a new species from Thailand. Adansonia, sér. 3 26: 63-66. 
Tagane S., Souladeth P., Rueangruea S., Okabe N., Zhang M., Chayer S., Yang C-J. \& Yahara T. 2017. Flora of Nam Kading National Protected Area II: 30 new records of Angiosperms for Laos. Edinburgh Journal of Botany 75: 107-116. https://doi.org/10.1017/S0960428617000361

Tagane S., Souladeth P., Zhang M. \& Yahara T. 2018. Flora of Nam Kading National Protected Area IV: Two new species of Annonaceae, Monoon namkadingense and Neo-uvaria laosensis. Phytotaxa 336: 82-88. https://doi.org/10.11646/phytotaxa.336.1.6

Thiers B. 2017. Index Hebariorum: A Global Directory of Public Herbaria and Associated Staff. New York Botanical Garden's Virtual Herbarium. Available from http://sweetgum.nybg.org/science/ih/ [accessed 10 Oct. 2019].

Thuong S.D., Bach T.T., Choudhary R.K., Tucker G.C., Cornejo X. \& Lee J. 2013. Capparis daknongensis (Capparaceae), a new species from Vietnam. Annales Botanici Fennici 50: 99-102.

https://doi.org/10.5735/085.050.0119

Thuong S.D., Bach T.T., Choudhary R.K., Tucker G.C., Hai D.V., Quang B.H., Chinh V.T. \& Lee J. 2015. Capparis gialaiensis (Capparaceae), a new species from Vietnam. Annales Botanici Fennici 52: 219-223. https://doi.org/10.5735/085.052.0314

Yang C.-J., Tagane S., Souladeth S., Okabe N., Hu J.-M. \& Yahara T. 2018. Flora of Nam Kading National Protected Area III: Begonia namkadingensis (Begoniaceae), a new species in limestone area. Phytotaxa 334: 195-199. https://doi.org/10.11646/phytotaxa.334.2.8

Zhang M. L. \& Tucker G.C. 2008. Capparaceae. In: Wu C.Y., Raven P.H. \& Hong D.Y. (eds) Flora of China. Vol. 7: 433-450. Science Press, Beijing, and Missouri Botanical Garden Press, St. Louis.

Manuscript received: 30 January 2020

Manuscript accepted: 27 March 2020

Published on: 1 June 2020

Topic editor: Frederik Leliaert

Desk editor: Radka Rosenbaumová

Printed versions of all papers are also deposited in the libraries of the institutes that are members of the EJT consortium: Muséum national d'histoire naturelle, Paris, France; Meise Botanic Garden, Belgium; Royal Museum for Central Africa, Tervuren, Belgium; Royal Belgian Institute of Natural Sciences, Brussels, Belgium; Natural History Museum of Denmark, Copenhagen, Denmark; Naturalis Biodiversity Center, Leiden, the Netherlands; Museo Nacional de Ciencias Naturales-CSIC, Madrid, Spain; Real Jardín Botánico de Madrid CSIC, Spain; Zoological Research Museum Alexander Koenig, Bonn, Germany; National Museum, Prague, Czech Republic. 


\section{Supplementary material}

Supplementary file 1

Key to the species of Capparis L. in Lao PDR. 